\title{
Konsumsi Jahe Untuk Mengatasi Mual Muntah Pada Ibu Bersalin Ny. D Trimester I Di BPM Deliana Kota Pekanbaru Tahun 2020
}

\author{
Rina Yulviana, Resti Utari \\ STIKes Hang Tuah Pekanbaru \\ Jl. Mustafa Sari No. 5 Tangkerang Selatan, Pekanbaru \\ rinayulviana@htp.ac.id \\ Resti.utari@yahoo.com
}

INTISARI

Latar belakang studi kasus: Mual muntah yang terjadi pada kehamilan trimester pertama disebabkan karena terjadi peningkatan kadar hormon Estrogen dan Human Chorionic Gonadotropine (HCG). Namun apabila terjadi berkelanjutan menjadi hiperemesis gravidarum dapat meningkatkan resiko terjadinya gangguan pada kehamilan.

Tujuan studi kasus: Laporan tugas akhir ini bertujuan untuk mengidentifikasi frekuensi morning sickness dan efektifitas pemberian jahe hangat dalam mengurangi frekuensi mual muntah pada ibu hamil trimester pertama.

Metode kasus: Metode yang digunakan adalah studi kasus. studi kasus yang dilakukan penulis yaitu asuhan pada ibu hamil trimester I mual muntah dengan pemberian air rebusan jahe untuk membantu mengurangi mual muntah di BPM Deliana S, Amd.Keb dari 03-07 September 2020. Subjeknya ibu hamil trimester 1 dengan mual dan muntah. Cara pengumpulan data anamnesa, observasi, pemeriksaan dan dokumentasi. Analisa data dengan membandingkan antara data yang di peroleh dari teori yang ada.

Hasil : Setelah di lakukan studi kasus asuhan kebidanan pada ibu hamil yaitu Ny. D di dapatkan hasil bahwa selama 4 hari dengan 2 x kunjungan kerumah pasien. Penulis tidak menemukan kesenjangan pada hasil subjektif dan objektif. Sehingga analisis dan penatalaksanaan sesuai dengan teori. Setelah dilakukan asuhan selama 4 hari didapatkan hasil bahwa ada pengurangan rasa mual dan muntah pada Ny. D dengan pemberian rebusan air jahe.

Saran : Diharapkan kepada penyedia layanan terutama bidan untuk pemberian air rebusan jahe menjadi referensi sebagai mengurangi mual dan muntah pada ibu hamil trimester 1 .

Kata Kunci: ibu hamil mual muntah, jahe 


\section{PENDAHULUAN}

Kehamilan adalah fertilisasi atau penyatuan dari spermatozoa dan ovum dan dilanjutkan dengan nidasi atau implantasi.

Dihitung dari saat fertilisasi hingga lahirnya bayi, kehamilan normal akan berlangsung dalam waktu 40 minggu (10 bulan atau 9 bulan) menurut kalender internasional. Kehamilan terbagi dalam 3 trimester, dimana trimester I berlangsung dalam 12 minggu, trimester II berlangsung 15 minggu (minggu ke-13 hingga minggu ke-27), dan trimester III 13 minggu (minggu ke-28 hingga minggu ke-40) (Prawirahardjo, 2014).

Kehamilan mempengaruhi tubuh ibu secara keseluruhan dengan menimbulkan perubahan-perubahan fisiologi yang terjadi diseluruh sistem organ, sebagian besar perubahan pada tubuh ibu kebanyakan disebabkan oleh kerja hormonal. Perubahan ini terjadi akibat adanya ketidakseimbangan hormone progestrogen dan estrogen yakni hormon kewanitaan yang ada didalam tubuh ibu sejak terjadinya proses ke/.hamilan (Mandriwati, 2008). Pada trimester pertama kemungkinan besar ibu hamil akan mengalami mual muntah. Gejala ini di mulai sekitar minggu ke enam kehamilan dan biasanya menurun drastis di akhir trimester pertama (sekitar minggu ke-13). Ini disebabkan perubahan saluran cerna dan peningkatan kadar Human Chorionic Gonadotropin (hCG) dalam darah menimbulkan beberapa keluhan yang membuat ibu merasa tidak nyaman saat kehamilan, diantaranya mual dan muntah (Mandriwati, 2008).

Emesis gravidarum akan bertambah berat menjadi hiperemesis gravidarum yang menyebabkan ibu muntah terus menerus tiap kali minum atau makan, akibatnya tubuh ibu semakin lemah, pucat, dan frekuensi buang air kecil menurun drastis sehingga cairan tubuh berkurang dan darah menjadi kental (hemokonsentrasi) sehingga memperlambat peredaran darah yaitu oksigen dan jaringan sehingga dapat menimbulkan kerusakan jaringan yang dapat membahayakan kesehatan ibu dan perkembangan janin yang dikandungnya (Hidayati, 2009).

Muntah yang terus menerus disertai dengan kurang minum yang berkepanjangan dapat menyebabkan terjadinya syok, dan dehidrasi yang berkepanjangan dapat dipastikan akan menghambat tumbuh kembang janin. Nutrisi yang adekuat selama kehamilan sangat diperlukan untuk kesehatan janin dan ibu hamil. Berat badan bayi baru lahir dan usia kehamilan terutama pada kelahiran premature berisiko menyebabkan kematian bayi baru lahir (Hanifa, 2007). 
Secara psikologis, mual dan muntah selama kehamilan menimbulkan efek yang signifikan terhadap quality of life. Sebagian ibu hamil merasakan mual dan muntah merupakan hal yang biasa terjadi selama kehamilan. Sebagian lagi merasakan sebagai sesuatu yang tidak nyaman dan mengganggu aktivitas seharihari, bahkan banyak wanita hamil yang harus mengkonsumsi obat-obatan atau tindakan alternatif lain untuk mengatasi mual dan muntah. Obat anti mual yang sering diberikan pada wanita hamil adalah vitamin B6. Namun obat ini dilaporkan memiliki efek samping seperti sakit kepala, diare, dan mengantuk (Laura, 2006).

Salah satu terapi mual muntah pada ibu hamil yang tidak memiliki efek samping yang dapat diberikan pada ibu hamil mual muntah adala minuman herbal berupa jahe. Berdasarkan penelitian yang dilakukan oleh (Ayu and Ardani, 2017) hasil penelitian didapatkan rata-rata frekuensi morning sickness sebelum diberikan minuman jahe hangat yaitu 13 kali dan setelah diberikan menurun menjadi 3,18 kali. Minuman jahe hangat memberikan pengaruh terhadap penurunan frekuensi mual muntah pada ibu hamil trimester pertama.

Kandungan jahe yang terdapat pada minyak Atsiri Zingiberena (zingirona), zingiberol, bilena, kurkumen, gingerol, flandrena, memiliki resin pahit yang dapat memblok serotinin yaitu suatu neurotransmitter yang disintesiskan pada neuron-neuron serotonergis dalam sistim syaraf pusat dan sel-sel enterokromafin dalam saluran pencernaan, akibatnya kerja otot-otot saluran pencernaan mengendur dan melemah kemudian menimbulkan perasaan nyaman dalam perut, sehingga mual dan muntah dapat berkurang (Ramadhan, 2013).

Hal ini sejalan dengan penelitian (Ika and Fanny, 2019) tentang Pengaruh Pemberian Minuman Jahe (Zingiber Officinale Var. Rubrum) Terhadap Penurunan Emesis Gravidarum Trimester Pertama hasil penelitian menyebutkan adanya perbedaan yang signifikan frekuensi emesis gravidarum sebelum dan sesudah diberikan minuman jahe di PMB Kota Padang tahun 2019 (Ramadhani and Ayudia, 2019). Penelitian ini juga didukung penelitian yang dilakukan oleh (Dyah, Dwi and Rofiatul, 2019) yaitu diketahui bahwa frekuensi mual muntah pada kelompok intervensi sebelum tindakan rata-rata skor 13.08, sedangkan setelah tindakan mendapatkan rata-rata skor 7.56. Hasil uji analisa Paired Samples $\mathrm{T}$ test (data berdistribusi normal) mendapatkan nilai p 0.000 yang menunjukkan bahwa pemberian minuman jahe efektif terhadap frekuensi emesis gravidarum pada ibu hamil trimester I di 
Puskesmas Nalumsari Jepara (Wulandari et al., 2019).

Berdasarkan survey data yang didapat penulis di BPM Deliana S Kota Pekanbaru, 3 dari 8 ibu hamil mual muntah yang diberikan obat-obatan kimia masih mengeluh mual dan muntah belum bisa teratasi dan sebagian mengeluh mengantuk sehingga merasa terganggu pada saat berkerja. Jahe merupakan salah satu terapi non farmakologis yang dapat digunakan oleh ibu hamil dalam mengatasi mual-muntah yang efektif yang tidak memiliki efek samping.

Berdasarkan paparan di atas, maka peneliti tertarik untuk melakukan studi kasus penggunaan terapi herbal minuman jahe untuk mengurangi mual muntah dengan judul "Asuhan Kebidanan Pada Ibu Hamil Mual dan Muntah Trimester I dengan Mengonsumsi Jahe di BPM Deliana S Kota Pekanbaru Tahun 2020”.

\section{METODE STUDI KASUS}

Metode yang di gunakan adalah studi kasus. Metode pengambilan studi kasus dilakukan dengan cara menentukan suatu permasalahan melalui suatu kasus yang terdiri dari unit tunggal. Unit yang menjadi kasus tersebut secara mendalam dianalisis baik segi yang berhubungan dengan keadaan kasus itu sendiri.
Pada laporan studi kasus yang dilakukan penulis yaitu asuhan pada ibu hamil trimester I mual muntah dengan pemberian air rebusan jahe dan sereh untuk membantu mengurangi mual muntah dengan menggunakan tujuh langkah varney dari pengkajian, evaluasi dan data perkembangan menggunakan SOAP.

\section{HASIL STUDI KASUS}

Asuhan Kebidanan Pada Ibu Hamil Kunjungan ke-I pada Ny. D pada Hari/ Tanggal : Kamis/ 3 September 2020, Pukul $: 10.00$ wib

\section{a. Data Subjektif}

- Ny. D umur 23 tahun, beragama kristen, alamat di jalan kubang, hamil anak pertama belum pernah keguguran, ibu merasa bahagia dengan kehamilan pertamanya.

- Keluhan yang dirasakan : ibu mengatakan mual muntah 6-8x, Ibu mengatakan HPHT nya tanggal 11 Juli 2020.

- Tidak ada riwayat penyakit yang pernah diderita ibu, suami dan keluarga senang atas kehamilan ibu.

- Pemenuhan kebutuhan sehari-hari: istirahat ibu cukup, ibu hanya bisa makan buah dan minum susu.

b. Data Objektif 
Keadaan umum ibu baik, tekanan darah 110/80 $\mathrm{mmHg}$, denyut nadi 82 $\mathrm{x} / \mathrm{i}$, pernafasan $21 \mathrm{x} / \mathrm{i}$, suhu $36,6{ }^{\circ} \mathrm{C}$, berat badan ibu $40 \mathrm{~kg}$, LILA ibu 23 $\mathrm{cm}$, kelopak mata ibu tidak pucat, konjungtiva merah muda, sklera putih, puting susu menonjol, ibu tidak ada merasakan benjolan maupun rasa nyeri, tfu: ball, tidak ada bekas luka operasi, kebersihan baik.

c. Assesment

Ny. D umur 23 tahun G1P0A0 mungkin hamil 7 minggu 4 hari dengan mual muntah.

d. Plan

- Hubungan baik dengan ibu.

- $\quad$ Beritahu hasil pemeriksaan ibu.

- Jelaskan kepada ibu tentang penyebab mual muntah, dan cara mengatasi mual-muntah

- Jelaskan pada ibu tentang manfaat jahe untuk mengatasi mual muntah, cara pembuatan, dan aturan minum

- Tanyakan kesediaan ibu menjadi responden untuk diberikan asuhan mengatasi mual muntah dengan mengonsumsi jahe.

- Jelaskan kebutuhan nutrisi pada ibu

- Jelaskan kebutuhan istirahat dan tidur pada ibu

- Jelaskan kepada ibu tanda bahaya kehamilan TM e. Implementasi

Informasi dan Edukasi :

a) Menjalin hubungan baik dengan ibu dan keluarga dengan penuh ramah dan sopan.

b) Menginformasikan hasil pemeriksaan kepada ibu dan keluarga bahwa keadaan umum ibu baik.

c) Memberikan penjelasan pada ibu bahwa mual muntah yang dialaminya merupakan hal yang umum terjadi pada kehamilan muda. Penyebab mual muntah pada ibu dikarenakan meningkatnya kadar hormone HCG yang mengakibatkan efek pedih pada lapisan perut berupa rasa mual. Untuk mengatasinya ibu bisa menghindari bau menyengat yang dapat memicu mual, makanan yang berminyak dan berlemak, makanan yang menimbulkan gas seperti ketimun, brokoli, kol, bawang, dan lobak.

d) Menjelaskan tentang manfaat air rebusan jahe untuk mengatasi mual muntah, bahwa jahe mengandung senyawa yang berguna bagi tubuh yaitu gingerol yang terbukti memiliki aktivitas antiemetic (anti muntah) yang menyebabkan perut berkontraksi sehingga otot saluran 
pencernaan melemah dan rasa mual banyak berkurang.

e) Menanyakan kesediaan pasien menjadi responden penulis dan kesediaan pasien untuk mengonsumsi jahe setiap dua kali sehari selama 4 hari.

f) Mengajarkan ibu cara pembuatan minuman jahe yaitu rebus 2,5 gram jahe atau setara dengan 2 irisan jahe dan mengajarkan aturan minum sesuai dengan anjuran dosis yang diberikan yaitu sehari $2 \mathrm{x}$.

g) Menjelaskan pada ibu tentang kebutuhan nutrisi pada ibu hamil dengan mual muntah, konsumsi makanan tinggi karboidrat dan protein seperti roti, biscuit, kacangkacangan, perbanyak minum air sesering mungkin, makan buahbuahan seperti pisang, alpukat. Menyarankan ibu untuk makan biscuit atau minum teh terlebih dahulu saat bangun tidur, makanlah sedikit-sedikit tapi sering.

h) Menganjurkan ibu untuk istirahat yang cukup, yaitu tidur malam 6-7 jam dan usahakan siangnya tidur/ berbaring 1-2 jam.Memberitahu ibu tanda bahaya kehamilan trimester 1 seperti mual muntah yang berlebihan, demam tinggi, bengkak kaki, tangan dan wajah atau sakit kepala disertai kejang, pendarahan

f. Evaluasi

- Ibu mengetahui hasil pemeriksaan

- ibu mengerti kondisi yang di alami dan mengerti tentang penyebab mual muntah serta cara mengatasinya.

- ibu mengerti manfaat jahe

- ibu bersedia menjadi responden dan bersedia meminum rebusan jahe

- ibu mengerti cara pembuatan minuman jahe

- ibu mengerti yang dijelaskan penulis

- ibu mengerti dan akan istirahat cukup

- ibu mengerti tanda bahaya kehamilan

\section{Kunjungan ke-II pada Ny."D"}

Hari/ tanggal : Minggu/ 6 September 2020, Pukul : 13.00 wib

1. Data Subjektif

Ibu mengatakan mual muntahnya sudah berkurang, ibu merasa kondisi lebih baik semenjak mengonsumsi rebusan jahe, ibu mengatakan memang mengonsumsi air rebusan jahe seperti yang disarankan peneliti, dan ibu setiap hari mengonsumsi jahe 2x sehari.

2. Data Objektif 
Keadaan umum ibu baik, tekanan darah 110/70 mmHg, denyut nadi 81 $\mathrm{x} / \mathrm{i}$, pernafasan $20 \mathrm{x} / \mathrm{i}$, suhu $36,6{ }^{\circ} \mathrm{C}$, kelopak mata ibu tidak pucat, sclera putihm dan conjungtiva merah muda.

3. Assessment

Ny. D umur 23 tahun G1P0A0 mungkin hamil 8 minggu, keadaan umum baik

4. Plan

Informasi dan Edukasi :

- Hubungan baik dengan ibu.

- Hasil pemeriksaan ibu.

- Ingatkan kembali kebutuhan nutrisi yang baik untuk ibu

- Motivasi ibu

5. Implementasi

a. Menginformasikan hasil pemeriksaan kepada ibu bahwa keadaan umum ibu baik.

b. Menganjurkan ibu untuk melanjutkan terapi yang diberikan bila masih terasa mual dan berhenti apabila mual-muntah sudah tidak dirasakan lagi.

c. Mengingatkan kembali pada ibu tentang kebutuhan nutrisi pada ibu hamil dengan mual muntah, konsumsi makanan tinggi karbohidrat dan protein seperti roti, biscuit, kacang-kacangan, perbanyak minum air sesering mungkin, makan buah-buahan seperti pisang, alpukat. Menyarankan ibu untuk makan biscuit atau minum teh terlebih dahulu saat bangun tidur, makanlah sedikit-sedikit tapi sering.

d. Memberikan motivasi pada ibu bahwa ibu pasti bisa melewati ketidaknyamanan pada kehamilan trimester pertamanya dan memberi pujian kepada ibu atas keberhasilan ibu karena telah mengikuti asuhan yang diberikan penulis

6. Evaluasi

a. Ibu mengetahui hasil pemeriksaan

b. Ibu mengatakan mual muntahnya berkurang menjadi $3 \mathrm{x}$

c. Ibu senang dengan keadaannya sekarang.

d. Ibu mengerti dan akan melanjutkan terapi sampai mual muntahnya hilang

\section{PEMBAHASAN}

\section{Data Subjektif}

Berdasarkan hasil yang diperoleh tentang efektivitas jahe dalam mengurangi mual muntah pada ibu hamil trimester I pada Ny. " $D$ " didapatkan bahwa pada kunjungan pertama sebelum dilakukan asuhan pemberian jahe ibu mengatakan mualmuntahnya 6-8x. Dan hari ke 4 ibu mengatakan mual-muntahnya 
berkurang dari sebelumnya menjadi $3 \mathrm{x}$ sehari.

Hal ini sejalan dengan penelitian Illuh Meta, dkk (2017) yang menyebutkan bahwa Penurunan frekuensi mual muntah terjadi pada hari 3 ke hari 4 dengan rata-rata penurunan sebesar 2,20. Sedangkan untuk penurunan sebelum dilakukan intervensi wedang jahe dan sesudah diberikan sampai hari ke-4, menunjukkan penurunan yang signifikan (Ningsih et al., 2018).

\section{Objektif}

Data objektif pada Ny. "D" kunjungan 1 yaitu keadaan umum ibu baik, tekanan darah 110/80 $\mathrm{mmHg}$, denyut nadi $82 \mathrm{x} / \mathrm{i}$, pernafasan $21 \mathrm{x} / \mathrm{i}$, suhu $36,6{ }^{\circ} \mathrm{C}$, berat badan ibu $40 \mathrm{~kg}$, LILA ibu $23 \mathrm{~cm}$, kelopak mata ibu tidak pucat, konjungtiva merah muda, sklera putih, puting susu menonjol, ibu tidak ada merasakan benjolan maupun rasa nyeri, tfu: ball, tidak ada bekas luka operasi, kebersihan baik. Pada teori asuhan kebidanan ibu hamil meliputi pemeriksaan keadaan umum, tanda vital, pemeriksaan fisik (muka, mulut, gigi, leher, dada, payudara, abdomen, extremitas atas dan bawah).

3. Plan

Penulis memberikan asuhan $\mathrm{Ny}$. "D" berdasarkan keluhan pasien yang mengatakan mual-muntah dengan anjuran kepada ibu untuk menghindari bau-bau atau makanan yang dapat memicu mual, menghindari makanan berminyak, menganjurkan ibu untuk makan sedikit-sedikit tapi sering, makan biscuit atau minum teh terlebih dahulu setelah bangun tidur pagi dan informasi mengenai minuman jahe yang bermanfaat untuk mengatasi mual muntah ibu hamil pada trimester 1, serta mengajarkan cara pembuatan minuman jahe.

\section{KESIMPULAN}

Setelah di lakukan studi kasus asuhan kebidanan pada ibu hamil yaitu Ny. D di dapatkan hasil bahwa selama 4 hari dengan 2 x kunjungan kerumah pasien, 1 kali lewat virtual dikarenakan pandemi ini penulis dan pasien mematuhi protocol kesehatan COVID-19.

Penulis tidak menemukan kesenjangan pada hasil subjektif dan objektif. Sehingga analisis dan penatalaksanaan sesuai dengan teori. Setelah dilakukan asuhan selama 4 hari didapatkan hasil bahwa ada pengurangan rasa mual dan muntah pada $\mathrm{Ny}$. D dengan pemberian rebusan air jahe.

\section{SARAN}

- Diharapkan kepada penyedia layanan terutama bidan untuk pemberian air 
rebusan jahe menjadi referensi sebagai mengurangi mual dan muntah pada ibu hamil trimester 1.

- Bagi instansi Pendidikan STIKes Hang Tuah Pekanbaru diharapkan studi kasus yang di lakukan dapat menambah wawasan pengetahuan mahasiswa khususnya D3 dan S1 kebidanan STIKes Hang Tuah Pekanbaru serta untuk di jadikan referensi.

- Bagi mahasiswa di harapkan dapat menambah pengetahuan dan keterampilan mahasiswa tentang asuhan kebidanan pada ibu hamil mual muntah trimester I dengan pemberian air rebusan jahe.

\section{DAFTAR PUSTAKA}

Ayu and Ardani (2017) 'Perbandingan Efektifitas Pemberian Terapi Minuman Jahe dengan Minuman Kapulaga Terhadap Morning Sickness pada Ibu Hamil Trimester I di Kelurahan Ngempong Kecamatan Bergas Kabupaten Semarang'.

Dyah, A. W., Dwi, K. and and Rofiatul, A. (2019) 'MINUMAN JAHE HANGAT UNTUK MENGURANGI EMESIS GRAVIDARUM PADA IBU HAMILDI PUSKESMAS NALUMSARI JEPARA', Jurnal SMART Kebidanan, 6(1), pp. 42-47.

Hanifa, W. (2007) Ilmu Kebidanan. Jakarta: Yayasan Bina Pustaka
Sarwono Prawirahardjo.

Hidayati, R. (2009) Asuhan Keperawatan pada Kehamilan Fisiologis dan Patologis. jakarta.

Ika, R. P. and Fanny, A. (2019) 'Pengaruh Pemberian Minuman Jahe (Zingiber Officinale Var. Rubrum) Terhadap Penurunan Emesis Gravidarum Trimester Pertama', Jurnal Ilmu Kesehatan, 3(2).

Laura, H. (2006) Treatment Option for Nausea and Vomiting During Pregnancy.

Mandriwati, G. A. (2008) Penuntun Belajar Asuhan Kebidanan Ibu Hamil. jakarta.

Ningsih, D. A. et al. (2018) 'Efektifitas Pemberian Wedang Jahe Terhadap Frekuensi Mual Dan Muntah Pada Ibu Hamil Trimester I', Jurnal Ilmu dan Teknologi Kesehatan, 5(2), pp. 201211.

Prawirahardjo (2014) ilmu kebidanan. jakarta.

Ramadhan, A. (2013) Aneka Manfaat Ampuh Rimpang Jahe untuk Pengobatan. Yogyakarta: Diandra Pustaka Indonesia.

Ramadhani, I. P. and Ayudia, F. (2019) 'Pengaruh Pemberian Minuman Jahe (Zingiber Officinale Var. Rubrum) Terhadap Penurunan Emesis Gravidarum Trimester Pertama', Jurnal Ilmu Kesehatan, 3(2), pp. 97- 
102.

Wulandari, D. A. et al. (2019) 'Minuman Jahe Hangat Untuk Mengurangi Emesis Gravidarum Pada Ibu Hamil
Di Puskesmas Nalumsari Jepara', Jurnal SMART Kebidanan, 6(1), pp. $42-47$. 